\title{
Peran Mediasi Perceived Value dalam Memediasi Pengaruh Experiental Marketing terhadap Behavioral Intention (Studi pada Wisata Wahana di Kota Batu)
}

\begin{tabular}{|c|c|c|}
\hline INFO ARTIKEL & \multicolumn{2}{|c|}{ Abstract } \\
\hline \multirow[t]{2}{*}{$\begin{array}{l}\text { Keywords: } \\
\text { Perceived Value, Behavioral } \\
\text { Intention, Experiental } \\
\text { Marketing }\end{array}$} & \multirow{2}{*}{\multicolumn{2}{|c|}{$\begin{array}{l}\text { The purpose of this study is to find out the role of perceived } \\
\text { value in mediating experiential marketing influence towards Behav- } \\
\text { ioral Intention of visitors in Wisata Wahana of Batu City. The sam- } \\
\text { ples were } 100 \text { respondents from visitors of Eco Green Park, Jatim Park } \\
\text { I and II. analysis technique using path analysis. The result of the study } \\
\text { shows that experiential marketing has significant and positive influ- } \\
\text { ence towards perceived value and Behavioral Intention. The per- } \\
\text { ceived value variable has been proven to be able to mediate experien- } \\
\text { tial marketing influence towards the Behavioral Intention of visitors } \\
\text { significantly, while the mediation happen is partial, because with- } \\
\text { out the perceived value variable as mediation, the experiential market- } \\
\text { ing variable can affect the Behavioral Intention. } \\
\text { Abstraks }\end{array}$}} \\
\hline & & \\
\hline $\begin{array}{l}\text { Kata Kunci: } \\
\text { Persepsi Nilai, Niat } \\
\text { Berperilaku, Eksperiental } \\
\text { Marketing } \\
\text { DOI: }\end{array}$ & \multicolumn{2}{|c|}{$\begin{array}{l}\text { Tujuan dari penelitian ini untuk mengetahui peran variabel } \\
\text { perceived value dalam memediasi experiental marketing terhadap } \\
\text { Behavioral Intention pada pengunjung wisata wahana di Kota Batu. } \\
\text { Jumlah sampel yang diambil pada penelitian ini sebanyak } \\
100 \text { orang. Hasil dari penelitian ini menunjukkan bahwa experiental } \\
\text { marketing berpengaruh positif dan signifikan terhadap perceived value } \\
\text { dan Behavioral Intention pengunjung wisata wahana Kota Batu. } \\
\text { Variabel perceived value dapat memediasi hubungan experiental } \\
\text { marketing terhadap Behavioral Intention secara posisitf dan } \\
\text { signifikan, namun mediasi yang terjadi adalah mediasi parsial karena } \\
\text { tanpa peran perceived value, variabel experiental marketing dapat } \\
\text { berpengaruh terhadap Behavioral Intention. }\end{array}$} \\
\hline \multicolumn{2}{|c|}{$\begin{array}{l}\text { Koresponsi: } \\
\text { Nama: Mohammad Fakhruddin Mudzakkir } \\
\text { Email: fakhruddin@unikama.ac.id, p-ISSN: 2355-9543 } \\
\text { email ivanurdiana@unikama.ac.id }\end{array}$} & $\begin{array}{l}\text { ISSN: } \\
\text { 2355-9543(Print) } \\
\text { ISSN: 2460-3775 } \\
\text { (on-line) }\end{array}$ \\
\hline
\end{tabular}

\section{PENDAHULUAN}

Pengembangan wisata semakin memiliki peran penting dalam pengembangan

ekonomi suatu daerah. Potensi kawasan menjadi daya tarik bagi wisatawan untuk mengunjungi daerah tersebut. Kota Batu merupakan salah satu kota yang concern terhadap pengembangan wisata, terdapat beragam tempat wisata baik alami, budaya maupun wahana yang digunakan untuk menarik minat wisatawan untuk mengunjungi tempat wisata tersebut. Beberapa tahun terakhir 


\section{Peran Mediasi Perceived Value dalam Memediasi Pengaruh,.. Mohammad Fakhruddin Mudzakkir1, Iva Nurdiana Nurfarida2}

jumlah wisatawan yang berkunjung di Kota Batu semakin meningkat, (Salim, 2016). Namun demikian pada tahun 2015 jumlah pengunjung wisata wahana di Kota Batu semakin menurun (Statistik Daerah Kota Batu, 2016). Oleh karena itu merupakan hal yang penting untuk melakukan studi terkait minat pengunjung khususnya pengunjung wisata wahana yang ada di Kota Batu.

Keputusan konsumen melakukan pembelian merupakan bagian dari perilaku konsumen yang merupakan domain ilmu pemasaran. Terdapat beberapa perspektif keputusan konsumen melakukan pembelian, diataranya yang paling dikenal adalah pendekatan rasional. Pada perspektif rasional keputusan konsumen diawali pengenalan masalah, pencarian informasi, membandingkan alternatif, memilih dan perilaku pasca pembelian (Dewey, 1978; Engel, Blackwell, \& Miniard, 1991; Mowen, 1988). Konsekuensi dari pendekatan ini adalah upaya konsumen dalam penyaringan informasi untuk memaksimumkan utilitas produk (Solomon, Bamossy, \& Askegaard, 2014).

Proses pengambilan keputusan konsumen dengan pendekatan rasional dilakukan melalui serangkaian proses yang sistematis dan berurutan. Padahal ada kalanya pengambilan keputusan pembelian konsumen tidak melalui serangkaian tahapan yang sistematis dan pasti tahapan keputusan pembelian tergantung dengan jenis dan karakteristik produk yang dibeli konsumen. Mowen (1988) menjelaskan salah satu kritik terhadap pendekatan rasional bahwa pendekatan rasional cenderung mengabaikan fenomena kegiatan rekreatif menyenangkan yang bersumber dari perasaan dan emosi, pendekatan ini disebut pendekatan experiental. Menurut Schmitt (1999) pendekatan experiential didorong oleh pencarian fantasi, feeling atau kesenangan. Pendekatan eksperiental dalam konteks pemasaran disebut sebagai experiental marketing.

Salah satu aspek penting dari perilaku konsumen adalah niat berperilaku (Behavioral Intention). Niat berperilaku merupakan hal yang penting karena terkait dengan perilaku yang sebenarnya. Niat berperilaku jika dipandang dari sudut pandang perusahaan, dapat dipahami sebagai konteks pemasaran relasional yang berusaha menciptakan customer retention. Hal ini karena, biaya akuisisi pelanggan baru, lebih mahal dari pada mempertahankan pelanggan yang ada (Berry, 2002), sehingga experiental marketing merupakan strategi intervensi pemasar mempengaruhi perilaku konsumen.

Bagi konsumen dalam konteks wisatawan, eksperiental merupakan kebutuhan hedonic terkait dengan emosi, perasaan dan mood, (Tsiotsou \& Goldsmith, 2012). Pemenuhan kebutuhan hedonic dalam hal ini emosi, perasaan dan mood konsumen akan meningkatkan niat berperilaku konsumen (Behavioral Intention). Implementasi pemenuhan kebutuhan hedonic terutama pengunjung wisata dapat diketahui melalui pengalaman pengunjung ketika mengunjungi tempat wisata (experiental marketing), semakin baik kualitas pengalaman pengunjung maka meningkatkan keinginan pengunjung untuk berperilaku kembali (Behavioral Intention). Konsep ini menurut penulis terdapat kekurangan yaitu persepsi nilai (perceived value). Perceived value pelanggan seharusnya menjadi variabel intervening dalam hubungan antara experiental marketing dengan Behavioral Intention. Hal ini karena konsumen selalu mengoptimalkan nilai atau manfaat yang diterima dalam mengambil keputusan pembelian (Kotler, 2001). Tujuan penelitian ini adalah untuk mengetahui apakah Behavioral Intention ditentukan oleh experiental marketing secara langsung dan melalui perceived value .

\section{KERANGKA KONSEPTUAL DAN HIPOTESIS}

\section{Experiental Marketing}

Konsep pemasaran dengan orientasi pengalaman konsumen merupakan

pengalaman perasaan afektif konsumen ketika mengalami manfaat psikologis dari pengalaman mengunjungi (Lian Chan \& Baum, 2007) yang tidak hanya ditentukan oleh atribut pemasar, namun juga ditentukan oleh pengunjung (Crompton \& Love, 1995). Schmitt (1999) menjelaskan bahwa suatu usaha yang digunakan oleh perusahaan atau pemasar untuk mengemas produk sehingga mampu menawarkan pengalaman emosi hingga menyentuh hati dan perasaan konsumen. Experiental marketing terdiri lima konsep, yaitu sense, feel, think, act, relate. Lebih lanjut Schmitt (1999) menjelaskan sense merupakan sejauh mana konsumen mendapatkan pengalaman melalui indera penglihatan, suara, sentuhan, rasa, dan bau. Feel merupakan penilaian perasaan konsumen dan informasi tentang merk dan perusahaan melalui pengalaman. Think merupakan keterlibatan konsumen dalam berpikir kreatif yang mungkin dihasilkan dalam bentuk penilaian kembali atas perusahaan dan produknya. Act berarti sejauh 
mana konsumen bertindak untuk menciptakan pengalaman terkait aktivitas fisik, gaya hidup, dan interaksi, adapun relate merupakan keterkaitan seseorang diluar diri konsumen seperti grup, masyarakat dan kelompok sosial lainnya.

Wisata wahana merupakan salah satu jenis wisata buatan dalam berbagai bentuk konsep wisata alam, kebudayaan, lingkungan dan taman inspiratif yang dikemas dalam berbagai bentuk permainan, edukasi dan wisata. Wisata jenis ini mengutamakan pengalaman yang dapat diberikan kepada konsumen. Pengalaman pengunjung ketika berada di tempat wisata sangat penting karena penilaian pengunjung ditentukan oleh pengalamannya selama proses kunjungan, (C.-F. Chen \& Chen, 2010). Chou (2009) menemukan bahwa experiental marketing berpengaruh terhadap perceived value. Berdasarkan kajian diatas maka hipotesis pada penelitian ini dapat dirumuskan sebagai berikut:

H1 : experiental marketing berpengaruh positif dan signifikan terhadap perceived value

\section{Perceived value}

Dalam melakukan pertukaran pelanggan selalu berupaya untuk mengoptimalkan

nilai yang didapat. Kotler (2001) mendefiniskan nilai pelanggan adalah selisih nilai pelanggan total dan biaya pelanggan total dimana nilai pelanggan total adalah sekumpulan total manfaat yang diharapkan oleh pelanggan dari produk atau jasa tertentu dibandingkan dengan total biaya yang dikeluarkan untuk mengevaluasi, mendapatkan, menggunakan dan membuang produk atau jasa. Oleh karena itu perusahaan harus menciptakan nilai sesuai yang diharapkan oleh pelanggan yang pada tingkatan tertentu juga menguntungkan perusahaan.

Penelitian tentang nilai pelanggan cukup banyak dilakukan. Zeithaml (1988) membagi 4 dimensi tentang persepsi nilai pelanggan: 1). Harga rendah, 2). Nilai bagi pelanggan adalah apa yang diinginkan pelanggan dalam suatu produk, 3). Nilai adalah kesesuaian kualitas dengan harga yang dibayar, 4). Nilai adalah kesesuaian apa yang didapat konsumen dengan apa yang diberikan oleh pelanggan. Beberapa peneliti mendefinisikan persepsi nilai merupakan penilaian terhadap tradeoff antara manfaat yang diterima dengan pengorbanan dalam memilih barang yang tersedia di pasar, (Z. Chen \& Dubinsky, 2003; McDougall \& Levesque, 2000; Sanchez-Fernandez \& Iniesta-Bonillo, 2007). Persepsi nilai tidak hanya diukur dalam satu konstruk namun multi dimensional konstruk, seperti halnya Sweeney and Soutar (2001) yang membagi persepsi nilai menjadi 4 dimensi; kualitas, emosional, harga, dan sosial. Sánchez, Callarisa, Rodríguez, and Moliner (2006) membagi persepsi nilai menjai 6 dimensi yaitu nilai fungsional travel agen, nilai profesionalisme dari kontak personel travel agen, nilai fungsional paket wisata yang dibeli, nilai fungsional harga, nilai emosi dan nilai sosial.

Peningkatan perceived value akan meningkatkan Behavioral Intention, atau penilaian penunjung pengunjung meningkat maka meningkatkan niat berperilaku di masa mendatang. Sehingga, persepsi nilai dianggap sebagai determinan penting dalam meningkatkan Behavioral Intention (Bajs, 2013; C.-F. Chen \& Chen, 2010). Berdasarkan kajian diatas maka hipotesis pada penelitian adalah:

$\mathrm{H} 2$ : peningkatan persepsi nilai akan meningkatkan niat berperilaku pengunjung.

\section{Behavioral Intention}

Hubungan antara pengunjung dengan perusahaan dapat dipandang dalam

konteks pemasaran relasional, yang bertujuan membangun dan mempertahankan hubungan jangka panjang dengan stakeholder kunci dengan dilandasi manfaat saling menguntungkan. Dalam rangka membangun dan mempertahankan hubungan jangka panjang dengan wisatawan maka diperlukan studi tentang niat berperilaku kembali. Ajzen and Fishbein (1970) mendefinisikan niat berperilaku sebagai kemungkinan subjektif (subjective probability) individu untuk berperilaku tertentu, niat berperilaku merupakan dimensi probabilitas subjektif seseorang yang menghubungkan antara dirinya dengan suatu tindakan tertentu. Dengan kata lain, niat merupakan besarnya dimensi probabilitas subjektif seseorang yang akan ditampilkan dalam bentuk perilaku tertentu. Niat berperilaku (Behavioral Intention) menurut Peter and Olson (2002) adalah suatu proposisi yang mengaitkan diri seseorang dengan tindakan orang tersebut dimasa mendatang. Terkait dengan pemasaran, Zeithaml, Berry, and Parasuraman (1996) menjelaskan bahwa niat berperilaku dapat berupa pembelian ulang, word of mouth, komplain dan sensitivitas harga.

Beberapa penelitian dilakukan untuk mengetahui bahwa hubungan eksperiental dengan kepuasan dan loyalitas pelanggan, (Alkilani, Ling, \& Abzakh, 2012; Ika \& Kustini, 2012; Jatmiko \& Andharini, 


\section{Peran Mediasi Perceived Value dalam Memediasi Pengaruh,..}

Mohammad Fakhruddin Mudzakkir1, Iva Nurdiana Nurfarida2

2012; Mustikasari, Yusiana, \& Wulansari, 2014; Pham \& Huang, 2012; Tsaur, Chiu, \& Wang, 2007; Wijaya \& Subagio, 2014). Studi terkait eksperiental marketing masih belum mampu mencakup keseluruhan perilaku konsumen yang potensial, (Cronin \& Taylor, 1992). Penelitian ini berusaha mengkaitkan hubungan eksperiental marketing dengan Behavioral Intention. Secara konseptual kualitas pengalaman (experiental quality) berpengaruh terhadap Behavioral Intention, (C.-F. Chen \& Chen, 2010). Oleh karena itu, hipotesis selanjutnya pada penelitian ini adalah:

H3 : Peningkatan eksperiental marketing akan meningkatkan Behavioral Intention.

\section{METODE}

Penelitian ini merupakan penelitian kuantitatif yang bertujuan untuk menguji hipotesis dan menjelaskan fenomena eksperiental marketing terhadap niat berperilaku melalui persepsi nilai sebagai variabel intervening. Teknik sampling menggunakan purposive yaitu pengunjung beberapa tempat wisata di Kota Batu meliputi Eco Green Park, Jatim Park I dan II. Jumlah sampel yang diambil sebanyak 100 responden. Variabel experiental marketing merujuk pada Schmitt (1999) yang membagi eksperiental marketing menjadi 5 dimensi yaitu sense, feel, think, act, dan relate. Variabel niat berperilaku merujuk pada Bajs (2013), adapun variabel persepsi nilai merujuk Lee, Yoon, and Lee (2007). Teknik analisis menggunakan path analysis.

\section{PEMBAHASAN}

\section{Validitas dan Reliabilitas}

Sebelum dilakukan pembahasan hasil penelitian dilakukan uji validitas dan

reliabilitas instrumen. Uji validitas pada tabel 1 menggunakan Pearson Correlation sehingga diketahui bahwa keseluruhan butir instrumen penelitian dinyatakan valid karena nilai butir $r$ hitung masing-masing lebih besar dari $r$ tabel $(0,202)$ sehingga setiap butir yang digunakan dalam penelitian ini dinyatakan valid. Adapun hasil uji reliabilitas pada tabel 2 menggunakan metode Cronbach's Alpha yang mensyaratkan bahwa instrumen dinyatakan reliabel jika nilainya lebih dari 0,6. Pada penelitian seluruh instrumen dinyatakan reliabel karena nilanya lebih besar dari 0,6 .

\section{Tabel 1. Uji Validitas}

\begin{tabular}{|l|l|l|l|}
\hline Variabel & $\begin{array}{l}\text { Notasi } \\
\text { Instrumen }\end{array}$ & $\begin{array}{l}\text { Pearson } \\
\text { Correlation }\end{array}$ & Keterangan \\
\hline Experiental marketing & $\mathrm{X} 1.1$ & 0,638 & Valid \\
\hline & $\mathrm{X} 1.2$ & 0,457 & Valid \\
\hline & $\mathrm{X} 1.3$ & 0,508 & Valid \\
\hline & $\mathrm{X} 1.4$ & 0,594 & Valid \\
\hline & $\mathrm{X} 1.5$ & 0,630 & Valid \\
\hline & $\mathrm{X} 1.6$ & 0,716 & Valid \\
\hline & $\mathrm{X} 1.7$ & 0,699 & Valid \\
\hline & $\mathrm{X} 1.8$ & 0,541 & Valid \\
\hline & $\mathrm{X} 1.9$ & 0,668 & Valid \\
\hline & $\mathrm{X} 1.10$ & 0,740 & Valid \\
\hline & $\mathrm{Y} 1.1$ & 0,714 & Valid \\
\hline & $\mathrm{Y} 1.2$ & 0,463 & Valid \\
\hline & &
\end{tabular}

\begin{tabular}{|l|l|l|l|}
\hline Variabel & $\begin{array}{l}\text { Notasi } \\
\text { Instrumen }\end{array}$ & $\begin{array}{l}\text { Pearson } \\
\text { Correlation }\end{array}$ & Keterangan \\
\hline & Y1.3 & 0,696 & Valid \\
\hline & Y1.4 & 0,520 & Valid \\
\hline & Y1.5 & 0,743 & Valid \\
\hline & Y1.6 & 0,490 & Valid \\
\hline & Y1.7 & 0,536 & Valid \\
\hline Behavioral Intention & Y2.1 & 0,698 & Valid \\
\hline & Y2.2 & 0,861 & Valid \\
\hline
\end{tabular}

Tabel 2.

Uji Reliabilitas

\begin{tabular}{|l|l|l|l|}
\hline Variabel & $\begin{array}{l}\text { Notasi } \\
\text { Instrumen }\end{array}$ & $\begin{array}{l}\text { Cronbach's } \\
\text { Alpha }\end{array}$ & Keterangan \\
\hline Experiental marketing & $\mathrm{X} 1$ & 0,796 & Reliabel \\
\hline Perceived value & $\mathrm{Y} 1$ & 0,771 & Reliabel \\
\hline Behavioral Intention & $\mathrm{Y} 2$ & 0,818 & Reliabel \\
\hline
\end{tabular}

Sumber: Data diolah 2015

\section{Hasil Analisis}

Evaluasi keseluruhan model dilakukan menggunakan analisis path yang digunakan untuk mengukur sejauh mana hubungan kausal antar variabel yang dilakukan melalui software SPSS 19. Hasil analisis path dapat dilihat pada tabel 3.

Berdasarkan substruktur path analysis pada tabel 3, maka persamaan strukturalnya sebagai berikut:

$Y 1=\beta 1 \mathrm{X}+\mathrm{e} 1$

$$
Y 2=0,398 \mathrm{X}+\mathrm{e} 1
$$

Berdasarkan analisis substruktur path 2 seperti yang ditunjukkan pada tabel 4, maka persamaan 


\section{Jurnal Studi Manajemen dan Bisnis}

Vol. 5 (2) 2018

strukturalnya sebagai berikut:

$Y 2=\beta 2 \mathrm{X}+\beta 3 \mathrm{Y} 1+\mathrm{e} 2$

$Y 2=0,206 \mathrm{X}+0,519 \mathrm{Y} 1+\mathrm{e} 2$

$e=\sqrt{1-R^{2}}$

Berdasarkan perhitungan pengaruh error (e) pada masing-masing substruktur maka hasil error pada substruktur 1 ( $\beta 1$ ) sebesar 0,918 dan pada substruktur $2(\beta 2)$ sebesar 0,778 .

$R_{m}^{2}=1-\left(\beta_{1}\right)^{2} \cdot\left(\beta_{2}\right)^{2}$

$=1-(0,918)^{2} \cdot(0,778)^{2}$

$=1-(0,842) \cdot(0,605)$

$=1-0,510$

$=0,49$

Hasil perhitungan terhadap nilai total determinasi diketahui sebesar 0,49. Hal ini berarti bahwa variasi variabel niat berperilaku dipengaruhi oleh variasi experiental marketing dan persepsi nilai sebesar $49 \%$, sedangkan sisanya sebesar $51 \%$ dipengaruhi oleh variabel lain yang tidak termasuk dalam model.

Tabel 3.

The Result of Linear Regression Analysis 1

UnstandardizedCoeffients

Standardized Coeffients

\begin{tabular}{|l|c|c|c|c|c|}
\hline Model & B & $\begin{array}{c}\text { Std. } \\
\text { Error }\end{array}$ & Beta & T & Sig. \\
\cline { 1 - 3 } (Constant) & 23,650 & 2,418 & & 9,779 & 0,000 \\
\hline Experiental marketing & 0,540 & 0,126 & 0,398 & 4,293 & 0,000 \\
\hline$R^{2}$ & 0,158 & & & \\
\cline { 1 - 2 } F Value & 18,426 & & & \\
\hline Sig. F & 0,000 & & & \\
\hline
\end{tabular}

Sumber: Data diolah 2016
Tabel 4 .

The Result of Linear Regression Analysis 2

\begin{tabular}{|l|c|c|c|c|c|}
\hline \multicolumn{3}{|c}{ Unstandardized Coeffients } & \multicolumn{3}{c}{ Standardized Coeffients } \\
\hline Model & B & $\begin{array}{c}\text { Std. } \\
\text { Enror }\end{array}$ & Beta & T & Sig. \\
\hline (Constant) & 2,236 & 1.481 & & 1.509 & 0.134 \\
\hline Experiental marketing & 0,144 & 0.060 & 0.206 & 2.403 & 0,018 \\
\hline Perceived value & 0,266 & 0.044 & 0,519 & 6.047 & 0,000 \\
\hline$R^{2}$ & 0,398 & & & & \\
\cline { 1 - 2 } & 32,027 & & & & \\
\hline F Value & 0,000 & & & & \\
\hline Sig. F & & & & \\
\hline Sumber: Data diolah 2016 & & & & \\
\hline
\end{tabular}

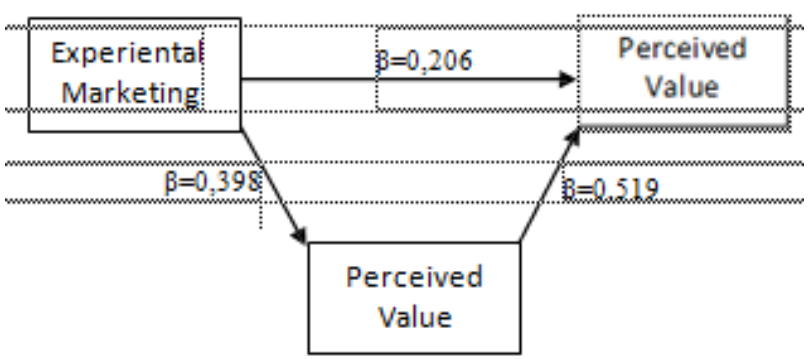

Diagram Path

Uji Hipotesis

(1) Uji signifikan t-test antara Marketing Experience $(X)$, terhadap Persepsi Nilai (Y1).

Hasil analisis diperoleh Standardized Coeffients Marketing Experience terhadap, Persepsi Nilai sebesar 0,398 pada tingkat probabilitas 0,000. Hasil pengujian diperoleh harga probabilitas $t$ hitung $0,000<0,05$ atau probabilitas hitung <level of significance $(\square)$ sehingga $\mathrm{H} 0$ ditolak, hal ini berarti bahwa terdapat pengaruh signifikan dan positif antara Marketing Experience terhadap Persepsi Nilai pada pengunjung Wisata Wahana di Kota Batu.

(2) Uji signifikan t-test antara Marketing Experience $(\mathrm{X})$, terhadap Behavioral

Intention (Y2).

Hasil analisis diperoleh Standardized Coeffients Marketing Experience terhadap Behavioral Intention sebesar 0,206 pada tingkat probabilitas 0,018 . Hasil pengujian diperoleh harga probabilitas t hitung 0,018<0,05 atau probabilitas hitung <level of significance $(\square)$ sehingga H0 ditolak, hal ini berarti bahwa terdapat pengaruh signifikan dan positif antara Marketing Experience $(X)$ terhadap Behavioral Intention (Y2) pada pengunjung Wisata Wahana di Kota Batu.

(3) Uji signifikan t-test antara Perceived value (Y1) terhadap Behavioral Intention

(Y2).

Hasil analisis di peroleh Standardized Coeffients Perceived value terhadap Behavioral Intention sebesar 0,519 pada tingkat probabilitas 0,000. Hasil pengujian diperoleh probabilitas t hitung 0,018 < 


\section{Peran Mediasi Perceived Value dalam Memediasi Pengaruh,.. Mohammad Fakhruddin Mudzakkir1, Iva Nurdiana Nurfarida2}

0,05 atau probabilitas hitung <level of significance ( $\square$ ) sehingga H0 ditolak, hal ini berarti bahwa terdapat pengaruh signifikan dan positif antara Perceived value (Y1) terhadap Behavioral Intention (Y2) pada pengunjung Wisata Wahana di Kota Batu.

(4) Pengujian Hipotesis Peran Mediasi

Uji Sobel digunakan untuk mengukur hubungan tidak langsung variabel hubungan variabel independen dan dependen yang dimediasi oleh variabel mediasi. Hasil perhitungan mensyaratkan pada derajat kepercayaan 95\% maka dengan $\mathrm{Z}$ value $>$

1,96 sehingga peran variabel mediator dapat memediasi antar variabel independen dan dependen secara signifikan.

$$
\begin{aligned}
& Z=\frac{0,398 \times 0,519}{\sqrt{0,519^{2} \times 0,126^{2}}+\sqrt{0,398^{2} \times 0,044^{2}}} \\
& Z=\frac{0,206}{0,067}=3,051
\end{aligned}
$$

Hasil perhitungan diatas diketahui bahwa $Z=3,051$ $>$ 1,96 dengan tingkat signifikansi 0,00, hal ini berarti variabel mediasi perceived dapat memediasi hubungan experiental marketing dengan Behavioral Intention

\section{PEMBAHASAN}

Uji hipotesis experiental marketing terhadap perceived value mempunyai

pengaruh positif dan signifikan menunjukkan bahwa peningkatan kualitas pengalaman konsumen ketika mengunjungi berbagai wisata wahana yang ada di Kota Batu meningkatkan penilaian manfaat yang diterima konsumen, atau dengan kata lain penilaian manfaat yang diterima oleh konsumen ditentukan oleh kualitas pengalaman yang diterima konsumen ketika berada di Wisata Wahana di Kota Batu. Hasil penelitian ini sesuai dengan penelitian yang dilakukan oleh Chou (2009) yang menunjukkan bahwa peningkatan pengalaman konsumen akan meningkatkan penilaian manfaat yang diterima konsumen.

Berdasarkan uji hipotesis yang telah dilakukan dapat diketahui bahwa experiental marketing berpengaruh positif dan signifikan terhadap niat berperilaku konsumen. Hal ini menunjukkan bahwa niat berperilaku konsumen ditentukan oleh pengalaman konsumen ketika mengunjungi berbagai tempat wisata wahana di Kota Batu. Hasil penelitian ini sesuai dengan penelitian yang dilakukan oleh Wijaya \& Subagio (2014) yang menunjukkan bahwa terdapat pengaruh positif dan signifikan experiental marketing terhadap Behavioral Intention.

Uji hipotesis perceived value terhadap Behavioral Intention mempunyai pengaruh positif dan signifikan hal ini menunjukkan bahwa peningkatan penilaian manfaat yang diterima oleh konsumen akan meningkatkan niat berperilaku konsumen di masa mendatang atau dengan kata lain niat berperilaku konsumen di masa mendatangditentukan oleh pengalaman yang diterima pengunjung ketika mengunjungi ketika berada di Wisata Wahana di Kota Batu. Hasil penelitian ini sesuai dengan penelitian yang dilakukan oleh Lee et. al. (2007), Bajs (2013), C.-F. Chen \& Chen (2010) yang menunjukkan bahwa peningkatan manfaat yang diterima konsumen akan meningkatkan niat konsumen untuk berperilaku dimasa mendatang.

Penelitian yang lain menjelaskan hubungan experiental marketing dengan variabel lain lebih banyak dikaitkan dengan kepuasan dan loyalitas konsumen secara langsung, (Jatmiko \& Andharini, 2012) atau experiental marketing dikaitkan dengan purchase intention melalui kepuasan pelanggan (Mustikasari et. al., 2014; Wijaya \& Subagio, 2014), experiental marketing berpengaruh terhadap kepuasan melalui perceived value, (Pham \& Huang, 2012). Beberapa penelitian tersebut tidak semua obyek penelitian menggunakan produk hiburan atau seni yang menawarkan pengalaman konsumen yang bersifat intangible product, namun sebagian berupa produk fisik tangible.

Berdasarkan uji mediasi dapat diketahui bahwa variabel perceived value dapat memediasi hubungan variabel experiental marketing dengan Behavioral Intention. Hal ini menunjukkan bahwa peningkatan experiental marketing akan meningkatkan perceived value sehingga akan meningkatkan Behavioral Intention pengunjung wisata wahana di Kota Batu.

\section{SIMPULAN DAN SARAN}

\section{Kesimpulan}

Keterbatasan penelitian ini bahwa hasil penelitian tidak dapat digenaralisasi

kepada seluruh populasi. Bagi perusahaan penyedia wisata wahana diharapkan dapat meningkatkan kualitas atribut wahana yang dapat meningkatkan pengalaman emosi dan perasaan konsumen sehingga konsumen benar-benar dapat 
merasakan nilai yang bermanfaat bagi konsumen sehingga akan meningktan niat berperilaku konsumen dimasa mendatang baik untuk mengunjungi kembali dan secara sukarela melakukan menyampaikan pengalaman yang didapat kepada orang lain.

Berdasarkan hasil analisis dapat disimpulkan bahwa (1) experiental marketing berpengaruh secara positif dan signifikan terhadap perceived value. Hal ini berarti peningkatan kualitas pengalaman yang didapat konsumen akan meningkatkan penilaian manfaat yang diterima konumen, (2) perceived value berpengaruh positif dan signifikan terhadap Behavioral Intention. Hal ini menunjukkan bahwa penilaian manfaat yang diterima konsumen akan meningkatkan niat berperilaku pengunjung dalam bentuk niat mengunjungi kembali dan menyampaikan pengalaman pengunjung kepada orang lain, (3) experiental marketing berpengaruh positif dan signifikan terhadap Behavioral Intention. Hal ini berarti bahwa peningkatan kualitas pengalaman konsumen akan meningkatkan niat pengunjung untuk mengunjungi kembali dan menyampaikan pengalaman pengunjung kepada orang lain, (4) variabel perceived value mampu memediasi hubungan antara experiental marketing dengan Behavioral Intention secara positif dan signifikan. Hal ini berarti bahwa penilaian pengunjung terhadap manfaat yang diterima pengunjung merupakan peran parsial karena pengunjung masih tetap berkeinginan untuk mengunjungi kembali dan menyampaikan pengalaman pengunjung kepada orang lain tanpa melakukan penilaian yang bermanfaat bagi dirinya.

\section{DAFTAR PUSTAKA}

Ajzen, I., \& Fishbein, M. (1970). The prediction of behavior from attitudinal and

normative variables. Journal of Experimental Social $\begin{array}{lll}\text { Psychology, 6(4), 466-487. } & \text { 6 }\end{array}$ doi:http://dx.doi.org/10.1016/00221031(70)90057-0

Alkilani, K., Ling, K. C., \& Abzakh, A. A. (2012). The Impact of Experiential Marketing and Customer Satisfaction on Customer Commitment in the World of Social Networks. Asian Social Science, 9(1). doi:10.5539/ass.v9n1p262

Bajs, I. P. (2013). Tourist Perceived value , Relationship to Satisfaction, and Behavioral Intentions: The Example of the Croatian Tourist Destination Dubrovnik. Journal of
Travel Research, 54(1), 122-134. doi:10.1177/0047287513513158

Berry, L. L. (2002). Relationship Marketing of Services Perspectives from 1983 and

2000. Journal of Relationship Marketing, 1(1), 59-77. doi:10.1300/J366v01n01_05

Chen, C.-F., \& Chen, F.-S. (2010). Experience quality, perceived value, satisfaction and Behavioral Intentions for heritage tourists. Tourism Management, 31(1), 29-

35. doi:10.1016/j.tourman.2009.02.008

Chen, Z., \& Dubinsky, A. J. (2003). A conceptual model of perceived customer value in ecommerce: A preliminary investigation. Psychology and Marketing, 20(4),

323-347. doi:10.1002/mar.10076

Chou, H. J. (2009). The Effect of Experiential and Relationship Marketing on Customer Value: a Case Study of International American Casual Dining Chains in Taiwan. Social Behavior and Personality: an international journal, 37(7), 9931007. doi:10.2224/sbp.2009.37.7.993

Crompton, J. L., \& Love, L. L. (1995). The Predictive Validity of Alternative

Approaches to Evaluating Quality of a Festival. Journal of Travel Research,

34(1), 11-24.

Cronin, J. J., \& Taylor, S. A. (1992). Measuring Service Quality: A Reexamination and

Extension. Journal of Marketing, 56(3), 55. doi: $10.2307 / 1252296$

Dewey, J. (1978). How We Think. Middle Work, 6(177-356).

Engel, J. F., Blackwell, R. D., \& Miniard, P. W. (1991). Consumer Behavior (6 ed.).

Chicago: Dryden Press.

Ika, N., \& Kustini. (2012). Experiential Marketing, Emotional Branding, And Brand Trust And Their Effect On Loyalty On Honda Motorcycle Product. Journal of Economics, Business and Accountancy Ventura, 14(1), 19-28.

Jatmiko, R. D., \& Andharini, S. N. (2012). Analisis experiential marketing dan loyalitas pelanggan jasa wisata (Studi pada Taman Rekreasi Sengkaling Malang). Jurnal Manajemen dan Kewirausahaan, 14(2), 128-137.

Kotler, P. (2001). Marketing_Management (Millenium ed.). New Jersey: Prentice-Hall, Inc.

Lee, C.-K., Yoon, Y.-S., \& Lee, S.-K. (2007). Investigating the relationships among perceived value, satisfaction, and recommendations: The case of the Korean DMZ. Tourism Management, 28(1), 204-214. 


\section{Peran Mediasi Perceived Value dalam Memediasi Pengaruh,... Mohammad Fakhruddin Mudzakkir1, Iva Nurdiana Nurfarida2}

doi:10.1016/j.tourman.2005.12.017

Lian Chan, J. K., \& Baum, T. (2007). Ecotourists' Perception of Ecotourism Experience in Lower Kinabatangan, Sabah, Malaysia. Journal of Sustainable Tourism,

15(5), 574-590. doi:10.2167/jost679.0

McDougall, G. H. G., \& Levesque, T. (2000). Customer satisfaction with services:

putting perceived value into the equation. Journal of Services Marketing, 14(5),

392-410. doi:10.1108/08876040010340937

Mowen, J. C. (1988). Beyond Consumer Decision Making. Journal of Consumer

Marketing, 5(1), 15-25. doi:10.1108/eb008214

Mustikasari, A., Yusiana, R., \& Wulansari, P. (2014, November 25-26). Experiential Marketing Strategy Analysis For Customer Satisfaction And Will Impact On Repeat Buying. Paper presented at the International Conference on Emerging Trends In Academic Research, Bali.

Peter, J. P., \& Olson, J. C. (2002). Consumer Behavior and Marketing Strategy (6 ed.): McGraw-Hill Irwin.

Pham, T. H., \& Huang, Y.-Y. (2012). The Impact Of Experiential Marketing On Customer's Experiential Value And Satisfaction: An Empirical Study In Vietnam Hotel Sector. Journal of Business Management \& Social Sciences Research, 4(1), 1-19.

Salim, M. A. (2016). Kunjungan Wisatawan di Kota Batu Tembus 3,5 Juta Orang.

Retrieved from

http://www.malangtimes.com/baca/8357/20 160105/185357/kunjungan- wisatawan-dikota-batu-tembus-35-juta-orang/

Sanchez-Fernandez, R., \& Iniesta-Bonillo, M. A. (2007). The concept of perceived value : a systematic review of the research. Marketing Theory, 7(4), 427-451. doi:10.1177/1470593107083165

Sánchez, J., Callarisa, L., Rodríguez, R. M., \& Moliner, M. A. (2006). Perceived value of the purchase of a tourism product. Tourism Management, 27(3), 394-409. doi:10.1016/j.tourman.2004.11.007

Schmitt, B. (1999). Experiential Marketing. Journal of Marketing Management, 15(1-

3), 53-67. doi:10.1362/026725799784870496

Solomon, M. R., Bamossy, G., \& Askegaard, S. (2014). Consumer behaviour: A European perspective (5 ed.). Harlow: Pearson Higher Education.

Statistik Daerah Kota Batu 2016 (35790.1607). Retrieved from Badan Pusat Statistik Kota Batu

Jawa

Timur:

https://batukota.bps.go.id/website/pdf_publi kasi/Statistik-Daerah-Kota-Batu-

2016.pdf

Sweeney, J. C., \& Soutar, G. N. (2001). Consumer perceived value : The development of a multiple item scale. Journal of Retailing, 77(2), 203-220.

Tsaur, S.-H., Chiu, Y.-T., \& Wang, C.-H. (2007). The Visitors Behavioral Consequences of Experiential Marketing. Journal of Travel \& Tourism Marketing, 21(1), 47-64. doi:10.1300/J073v21n01_04

Tsiotsou, R. H., \& Goldsmith, R. E. (2012). Introduction to experiential marketing. In R. H. Tsiotsou \& R. E. Goldsmith (Eds.), Strategic Marketing in Tourism Services: Emerald Group Publisihing Limited.

Wijaya, A., \& Subagio, H. (2014). Analisis Pengaruh Experiential Marketing Terhadap Repeat Purchase Dengan Customer Satisfaction Sebagai Mediating Variable Di De Mandailing Cafe UC Boulevard Surabaya. Jurnal Strategi Pemasaran, 2(1),

$1-9$

Zeithaml, V. A. (1988). Consumer Perceptions of Price, Quality, and Value: A Means- End Model and Synthesis of Evidence Journal of Marketing, 52(3).

Zeithaml, V. A., Berry, L. L., \& Parasuraman, A. (1996). The Behavioral Consequences of Service Quality. Journal of Marketing, 60(2), 31. doi:10.2307/1251929 
Jurnal Studi Manajemen dan Bisnis

Vol. 5 (2) 2018

Lampiran

\begin{tabular}{|c|c|c|}
\hline Variabel & $\begin{array}{c}\text { Sub } \\
\text { Variabel }\end{array}$ & Indilkator \\
\hline \multirow{10}{*}{$\begin{array}{l}\text { Experiental } \\
\text { marketing }\end{array}$} & Sense & Tempat wisata yang asya kunjungi menarik \\
\hline & & $\begin{array}{l}\text { Saya terkesan dengan tempat wisata yang asya } \\
\text { kunjungi }\end{array}$ \\
\hline & Feel & $\begin{array}{l}\text { Tempat wisata yang saya kunjungi mampu } \\
\text { membawa saya pada suasana hati tertentu }\end{array}$ \\
\hline & & $\begin{array}{l}\text { Saya merasakan suasana di tempat wisata yang } \\
\text { saya kunjungi sesuai dengan perasaen saya }\end{array}$ \\
\hline & Think & $\begin{array}{l}\text { Tempat wisata yang saya knjungi meningkatkan } \\
\text { keingintahuan saya untuk mengetahui hal-hal } \\
\text { yang belum saya ketahui di tempat wisata } \\
\text { tersebut }\end{array}$ \\
\hline & & $\begin{array}{l}\text { Tempat wisata yang saya kunjungi mendorong } \\
\text { asya untuk berpikir kreatif }\end{array}$ \\
\hline & Act & $\begin{array}{l}\text { Saya alkan memberitahulan pengalaman } \\
\text { berkunjung ke tempat wisata ini kepada orang } \\
\text { lain }\end{array}$ \\
\hline & & $\begin{array}{l}\text { Saya mengambil beberapa gambar foto di tempat } \\
\text { wisata yang saya kunjungi }\end{array}$ \\
\hline & Relate & $\begin{array}{l}\text { Saya akan membeli beberapa cinderamata terkait } \\
\text { tempat wisata yang asya kunjungi }\end{array}$ \\
\hline & & $\begin{array}{l}\text { Berkunjung ke tempat wisata ini membuat saya } \\
\text { sadar akan pelestarian linghungan. }\end{array}$ \\
\hline \multirow[t]{3}{*}{ Persepsi Nilai } & $\begin{array}{l}\text { Flunctional } \\
\text { value }\end{array}$ & $\begin{array}{l}\text { Harga yang asya bayar di tempat wisata ini } \\
\text { cukup hemat }\end{array}$ \\
\hline & & $\begin{array}{l}\text { Dibandingkan dengan tempat wisata lainnya, } \\
\text { harga yang saya bayarkan sesuai dengan manfaet } \\
\text { yang saya dapatkan }\end{array}$ \\
\hline & & $\begin{array}{l}\text { Menurut saya, tempat wisata yang saya kunjungi } \\
\text { mempunyai kualitas yang baik }\end{array}$ \\
\hline
\end{tabular}

\begin{tabular}{|c|c|c|}
\hline Variabel & $\begin{array}{l}\text { Sub } \\
\text { Variabel }\end{array}$ & Indikator \\
\hline & $\begin{array}{l}\text { Orerall } \\
\text { rałue }\end{array}$ & $\begin{array}{l}\text { Berkunjung ke tempat wisata ini merupakan hal } \\
\text { yang patut diapresiasi dan layak }\end{array}$ \\
\hline & & $\begin{array}{l}\text { Manfast yang saya terima ketika mengunjungi } \\
\text { tempat wisata ini lebih dari yang saya haraplan }\end{array}$ \\
\hline & $\begin{array}{l}\text { Emotional } \\
\text { Value }\end{array}$ & $\begin{array}{l}\text { Mengunjungi tempat wisata ini menupakan hal } \\
\text { yang menyenangkan }\end{array}$ \\
\hline & & $\begin{array}{l}\text { Mengunjungi tempat wisata ini membus } \\
\text { perassan saya menjadi lebih baik }\end{array}$ \\
\hline \multirow[t]{2}{*}{ Niat berperilaku } & & $\begin{array}{l}\text { Saya akan berkunjung kembali ke tempat wisata } \\
\text { ini di masa mendatang }\end{array}$ \\
\hline & & $\begin{array}{l}\text { Saya berkeinginan untuk menyampaikan } \\
\text { pengalaman lunjungan saya ke tempat wisata ini } \\
\text { kepada orang lain }\end{array}$ \\
\hline
\end{tabular}

